\section{Four new lycaenid butterfly records from the Kumaon Himalaya, India}

\section{Peter Smetacek}

The Retreat, Jones Estate, Bhimtal, Nainital, Uttarakhand 263136, India

Email: petersmetacek@rediffmail.com

During the last two decades, there have been reports of range extensions for several species of butterflies to the western Himalaya. Almost all of these reports have resulted from work in the Indian state of Uttarakhand, comprising the administrative divisions of Kumaon and Garhwal that lie to the west of Nepal. These include Plebejus eversmanni Staudinger (Smetacek 1992), Rapala pheretima Hewitson (Smetacek 1995), Talicada nyseus GuérinMenéville (Singh 2005a), Poritia hewitsoni Moore (Singh 2003a), Ampittia dioscorides Fabricius (Singh 2003b), Delias acalis Godart (Smetacek 2001), Pontia daplidice and Pontia glauconome (Smetacek 2002) and Zesius chrysomallus Hübner (Singh 2005b). In addition, populations of some butterflies like Pazala mandarinus garhwalica Katayama (Katayama 1986) and Meandrusa lachinus Fruhstorfer (Singh 2006) have been discovered recently.

In the present paper, four species are reported for the first time from the Kumaon Himalaya. All were recorded at low elevation at the base of the outermost

Date of publication (online): 26 February 2011

Date of publication (print): 26 February 2011

ISSN $0974-7907$ (online) | 0974-7893 (print)

Editor: Krushnamegh Kunte

Manuscript details:

Ms \# 02224

Received 30 May 2009

Final received 30 April 2010

Finally accepted 22 December 2010

Citation: Smetacek, P. (2011). Four new lycaenid butterfly records from the Kumaon Himalaya, India. Journal of Threatened Taxa 3(2): 15551558

Copyright: (C) Peter Smetacek 2011. Creative Commons Attribution 3.0 Unported License. JoTT allows unrestricted use of this article in any medium for non-profit purposes, reproduction and distribution by providing adequate credit to the authors and the source of publication.

Acknowledgements: A part of this work was funded by the Rufford Small Grants Foundation, for which the author is very grateful.

\section{OPEN ACCESS | FREE DOWNLOAD (C) (i) (4)}

range, in a predominantly sal (Shorea robusta) forest biotype. Of these, one (Talicada nyseus Guérin-Menéville) has already been reported from Dehra Dun (Singh 2005a), yet I report it since the first specimen from Kumaon was recorded a year and a half before Singh's (2005a) specimens, which were recorded in May and June 2003.

\section{Red Pierrot Talicada nyseus nyseus Guérin- Menéville (Image 1)}

Material Examined: 9 exs: 21.i.2002 (female), Haldwani, $29^{\circ} 12^{\prime} 48^{\prime \prime} \mathrm{N} \& 7^{\circ} 34^{\prime} 17^{\prime} \mathrm{E}$, 400m, JoTT 2011-01, JoTT 2011-02, JoTT 2011-03, JoTT 201104, JoTT 2011-05, JoTT 2011-06, JoTT 2011-07, JoTT 2011-08, JoTT 2011-09; 31.i.2006, Haldwani, 400m; 7.vii.2003, Chandadevi 800m; 12.vii.2006, Chandadevi, 800m; 23.vii.2003 Chandadevi, 800m; 9.viii.2003, Chandadevi, 800m; 2.ix.2003, Celery, 1000m; 21.ii.2004, Jones Estate, Bhimtal, 29021'17'N \& 79032'34”E, 1500m; 5.vi.2006, Jones Estate, Bhimtal, 1500m. Legit et collectavit (Leg. et Coll.) P. Smetacek.

Forewing length: 14-20 mm.

Distribution: Sri Lanka, southern India, Dehra Dun to Thailand. Delhi (Smetacek 2009).

Remarks: In addition to the above specimens, the species was recorded at Gethia Sanatorium $1500 \mathrm{~m}$ elevation (25.ii.2006); Bohrakoon 1300m (22.ix.2005; 14.xi.2005); Jones Estate, Bhimtal 1500m (2.xi.2008;

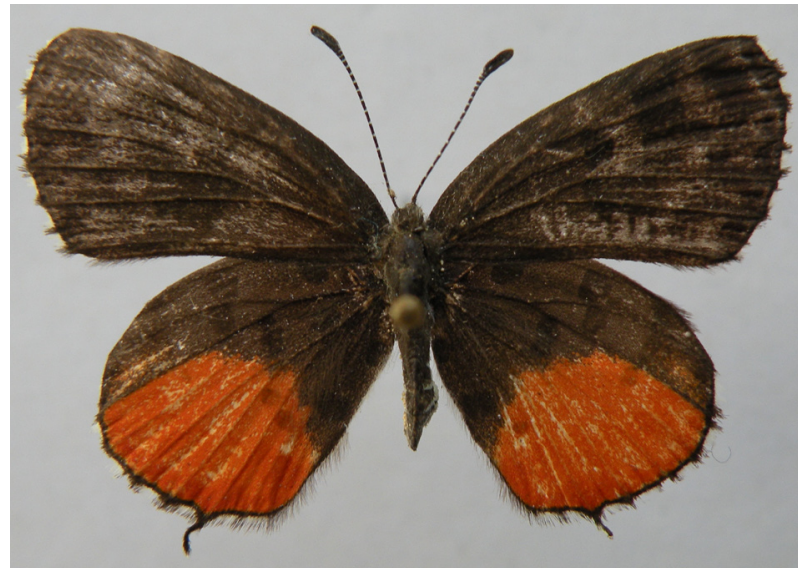

Image 1. Red Pierrot Talicada nyseus nyseus 

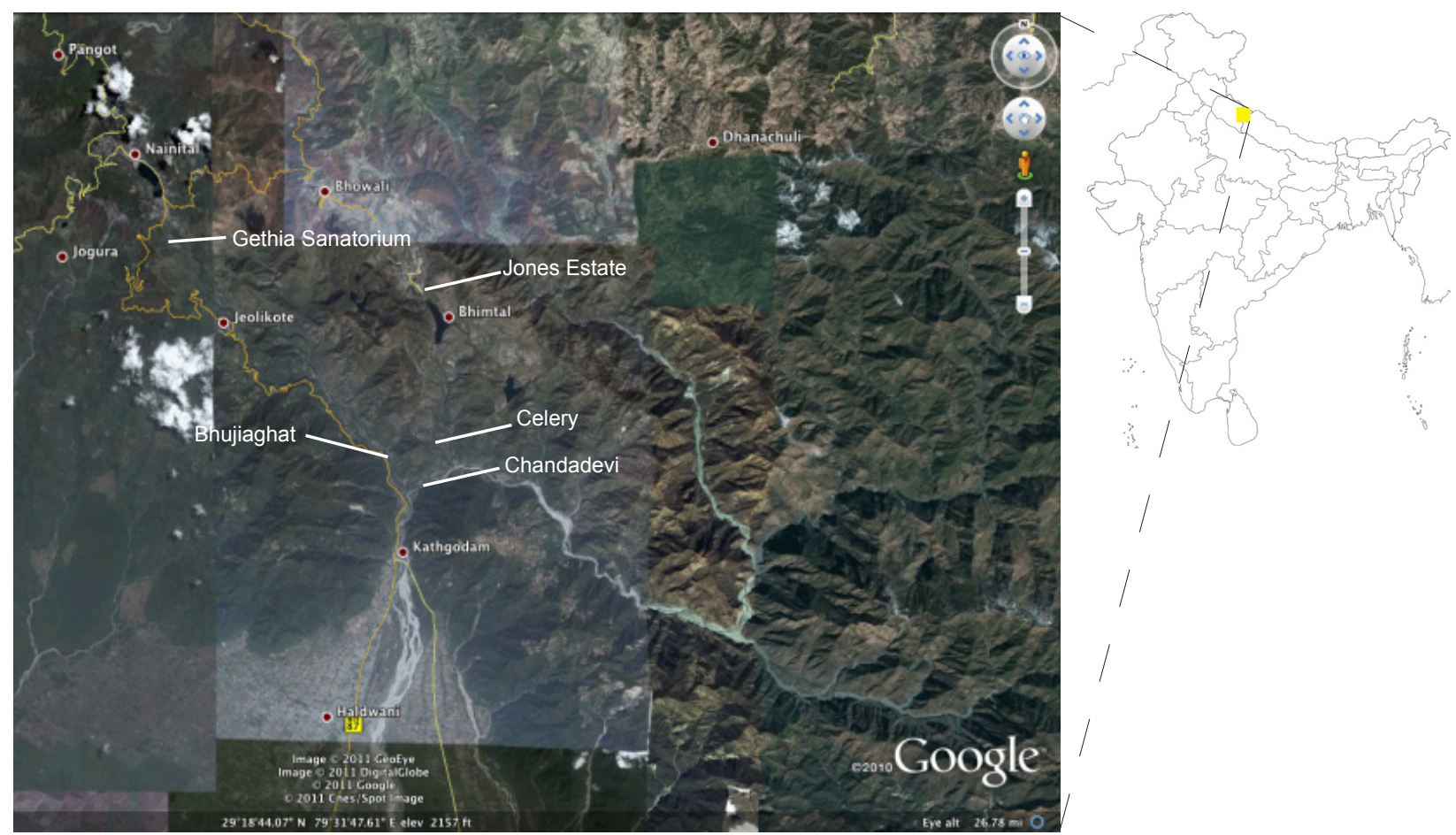

Image 2. Areas of collection of lycaenids.

18.ix.2005) and Haldwani 400m (11.viii.2004).

The species occurs along the Himalaya from Dehra Dun eastwards and also in Delhi (Smetacek 2009). There are no reports of the species from the area between Dehra Dun and Delhi and the possibility that the distribution is disconnected cannot be ruled out.

All the locations mentioned above, except Gethia Sanatorium, are on the motor road between Haldwani and Bhimtal. Jones Estate is in the Bhimtal Valley. Gethia Sanatorium is on the road between Haldwani and Bhowali.

The earliest report of this butterfly from the Kumaon Himalaya was by Atkinson (1882), who added an interrogation mark, suggesting that he was uncertain of the record. This report was subsequently ignored by authors (Hannyngton 1910; Evans 1932; Peile 1937; Wynter-Blyth 1957) who did not find the butterfly.

The first specimen of this butterfly, a female, was recorded in the middle of Haldwani Town (400m) on 21.i.2002 as it crossed a busy road and dived into a fruit seller's pile of oranges. Numerous records followed, as it ascended the hills during the succeeding years, from Haldwani 400m, 21.i.2002; Chandadevi 800m, 7.vii.2003; Celery 1000m, 2.ix.2003; Jones Estate $1500 \mathrm{~m} \mathrm{21.ii.2004.} \mathrm{It} \mathrm{is} \mathrm{now} \mathrm{well} \mathrm{established} \mathrm{in} \mathrm{the}$ area and is on the wing during January, February, June, July, August, September and November.

The species bears a large orange area on the distal half of the hindwing recto. Evans (1932) noted that this orange area is extensive, with a width of $1 / 4$ inch, in the southern Indian subspecies nyseus, while it is restricted, well under $1 / 4$ inch, in the east Himalayan subspecies khasiana Swinhoe. In addition, the markings on the hindwing verso are reduced in nyseus, with most of the discal band absent. In khasiana, these markings are large and complete.

The specimens examined have a wide orange area on the hindwing recto, $1 / 4$ inch or more. On the hindwing verso, all the specimens examined except one (Jones Estate 21.ii.2004) have an incomplete discal band. This latter specimen is not as heavily marked on the verso surface as the specimen depicted in Evans (1932), so it is reasonable to place it under ssp. nyseus.

This suggests that the present infiltration originated in southern India. It is possible, as Singh (2005a) suggests, that the species was carried in succulent plants brought from southern India and, finding the climate conducive, managed to colonise the area. This, however, overlooks Atkinson's (1882) record and the fact that its known larval foodplant, Kalanchoë 


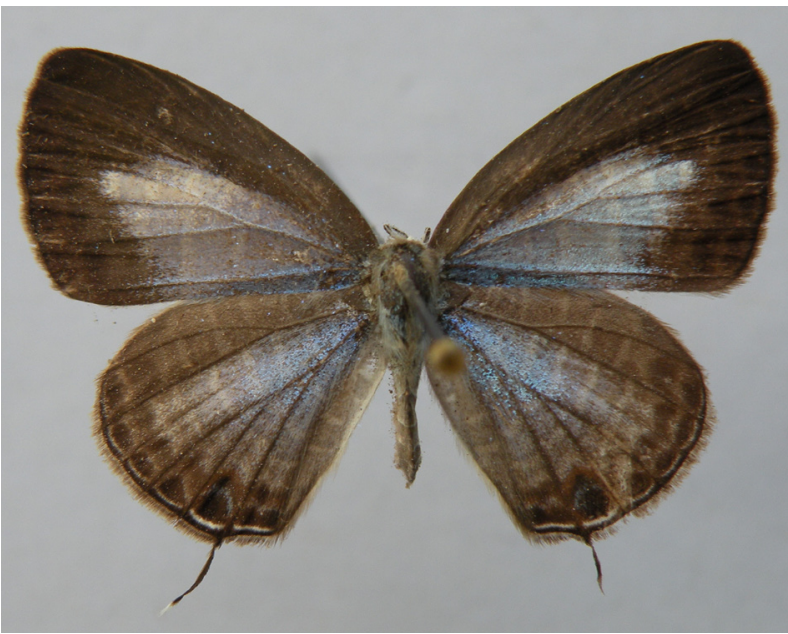

Image 3. Transparent Six-line Blue Nacaduba kurava

spathulata DC, is indigenous to the area. This, in turn, suggests that the butterfly existed all along in the area, albeit at very low densities and has now become commoner, enabling it to be recorded again.

The specimens recorded from Chandadevi were part of a colony thriving in a small patch of Kalanchö growing on the hillside bordering the road. There were usually four to five individuals about at any given time. When the Public Works Department cleared the undergrowth bordering the road in September 2003, the Kalanchö plants were cut, following which the population of $T$. nyseus was wiped out and neither the plants nor the butterfly ever recovered.

\section{Transparent Six-line Blue Nacaduba kurava Moore (Image 3)}

Material Examined: 2 exs.: Bhujiaghat 700m, JoTT 2011-10, JoTT 2011-11, 5.vi.2003 female; Bhujiaghat 700m, 26.iv.2004 female. Leg. et coll. P. Smetacek.

Forewing Length: 12-15 mm.

Distribution: Sri Lanka, southern India and from Nepal to Australia.

Remarks: The present records constitute a westward extension to the known distribution of this species. There were several females about, of which I took one on each occasion. Unfortunately, I could not find a male, so it is not possible to ascertain the subspecies to which this population belongs, since the distinction is based on males.

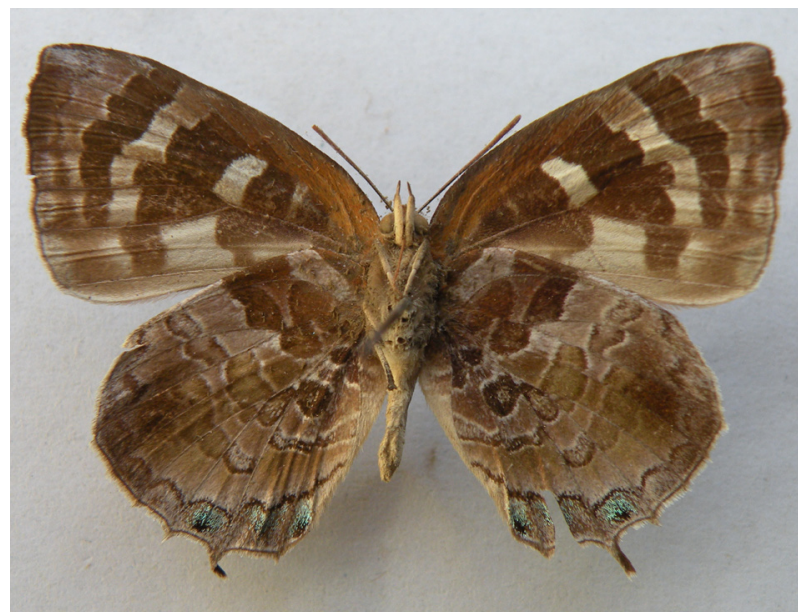

Image 4. Spangled Plushblue Flos asoka (underside)

\section{Spangled Plushblue Flos asoka de Nicéville (Image 4)}

Material Examined: 4 exs.: Bhujiaghat 700m, JoTT 2011-12, JoTT 2011-13, JoTT 2011-14, JoTT 201115, 31.v.2003 x2 males; Bhujiaghat 700m, 2.vi.2003 male; Bhujiaghat 700m, 20.v.2005 male. Leg. et coll. P. Smetacek.

Forewing Length: 20-21 mm.

Distribution: Nepal eastwards along the Himalaya to Thailand and Hong Kong.

Remarks: A rather common butterfly in Bhujiaghat. It keeps to the tree tops and descends occasionally to drink at damp mud. The flight is swift. In flight, the pale underside serves to distinguish this species from members of the Arhopala Boisduval genus.

\section{Aberrant Bushblue Arhopala abseus indicus Riley (Image 5)}

Material Examined: 1 ex.: Bhujiaghat 750m, JoTT 2011-16, 31.v.2003 male. Leg. et coll. P. Smetacek.

Forewing Length: $15 \mathrm{~mm}$.

Distribution: Southern India and from Nepal to Tavoy. Other subspecies are found in South East Asia, the Philippines and Sulawesi.

Remarks: This is a westward extension to the known distribution of this species. The specimen recorded descended from the rather high canopy and settled briefly on a leaf some $3 \mathrm{~m}$ above the ground. It is likely that the species is commoner at the canopy level than it is at ground level. 


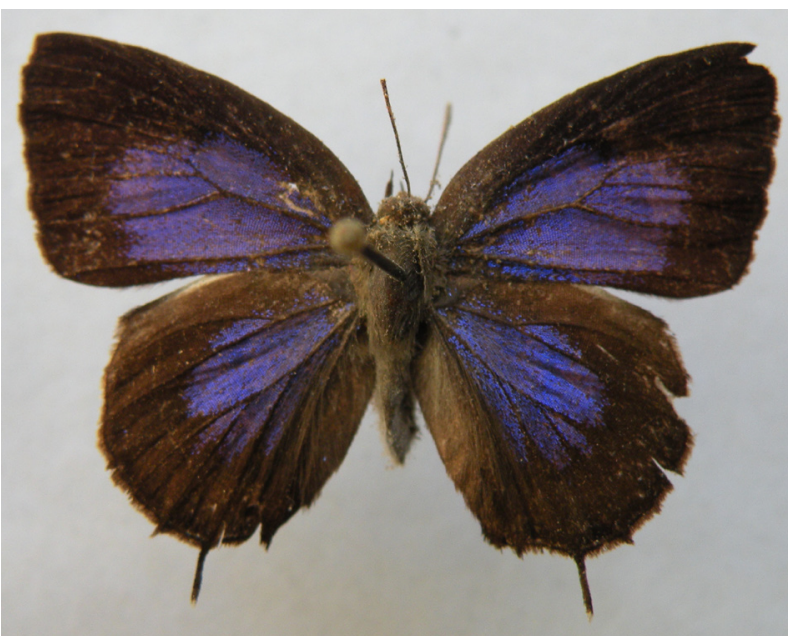

Image 5. Aberrant Bushblue Arhopala abseus indicus

\section{Discussion}

Visits at the same season in subsequent years to the site yielded no further records of $A$. abseus, although Flos asoka was observed in 2004. In the summer of 2008 , the entire area was devastated by a major forest fire and no butterflies were visible in the months following the fire.

Barring Talicada nyseus, for which nothing certain can be construed one way or another, the present records do not seem to be recent range extensions. It is likely that these butterflies have always been in the area, but the season at which they occur, the height of summer, prevented earlier surveys. Suffice it to say that these butterflies were on the wing around noon on sunny days, a time when the temperature was extremely uncomfortable, even in the shade.

\section{REFERENCES}

Atkinson, E.T. (1882). The Himalayan Districts of the North West Provinces of India. Vol. 2, Chapter 2, Zoology (Invertebrata). Government Press, Allahabad, 87-266pp.

Evans, W.H. (1932). The Identification of Indian Butterflies $2^{\text {nd }}$ Edition. Bombay Natural History Society, Bombay, $10+454 \mathrm{pp}+32 \mathrm{pl}$.

Hannyngton, F. (1910). The butterflies of Kumaon. Journal of the Bombay Natural History Society 20: 130-142; 361372.
Katayama, T. (1986). Notes on Pazala glycerion (Gray), with description of a new subspecies from northwest India. Gekkan-Mushi 203: 8-9, pl.1.

Peile, H.D. (1937). A Guide to Collecting Butterflies of India. Staples Press, London, $14+361 \mathrm{pp}+25 \mathrm{pl}$.

Singh, A.P. (2003a). New records on the distribution and ecology of Common Gem Butterfly Poritia hewitsoni hewitsoni Moore from the lower western Himalayas: a lesser known taxa. Journal of the Lepidopterists' Society 37 (4): 295-298.

Singh,A.P. (2003b). Distribution range extension of bush hopper butterfly, Ampittia dioscorides Fabricius (Lepidoptera: Hesperidae) into the lower western Himalayas. Indian Forester 129(8): 1046-1048.

Singh, A.P. (2005a). Initial colonization of Red Pierrot butterfly, Talicada nyseus nyseus Guerin (Lycaenidae) in the lower western Himalayas: an indicator of the changing environment. Current Science 89: 41-42.

Singh, A.P. (2005b). Recent records on the distribution, seasonality and occurrence of Redspot butterfly, Zesius chrysomallus Hübner from the lower western Himalayas. Journal of the Bombay Natural History Society 102(2): 238-239.

Singh, A.P. (2006). Range extension of Brown Gorgon butterfly, Meandrusa gyas gyas Westwood into Kedarnath Musk Deer Reserve, Western Himalayas: A lesser known species from north-east India. Indian Forester 132(12a): 187-189.

Smetacek, P. (1992). Record of Plebejus eversmanni (Staudinger) (Lepidoptera: Lycaenidae) from India. Journal of the Bombay Natural History Society 89: 385-386.

Smetacek, P. (1995). A new altitudinal and range record for the Copper Flash butterfly Rapala pheretimus Hewitson (Lepidoptera: Lycaenidae). Journal of the Bombay Natural History Society 92: 127-128.

Smetacek, P. (2001). Resolution of the controversial western limit of the range of Delias acalis Godart (Lepidoptera: Pieridae). Journal of the Bombay Natural History Society 98: 298-300.

Smetacek, P. (2002). The genus Pontia Fabricius (Lepidoptera: Pieridae) in the Kumaon Himalaya. Journal of the Bombay Natural History Society 99: 224-231.

Smetacek, P. (2009). Additions to the butterflies of Delhi. Bionotes 11(1): 15.

Wynter-Blyth, M.A. (1957). Butterflies of The Indian Region. Bombay Natural History Society, Bombay, $20+523 p p+72 p l$. 